\title{
POLITIK HUKUM PEMBENTUKAN UNDANG-UNDANG PERLINDUNGAN SAKSI DAN KORBAN, DILIHAT DARI PERLINDUNGAN WHISTLEBLOWER (SAKSI PELAPOR) DAN SAKSI AHLI DI INDONESIA ${ }^{48}$
}

\author{
ARIS IRAWAN \\ Email: arisirawan@borneo.ac.id \\ Dosen Pascasarjana Ilmu Hukum Univ. Borneo Tarakan
}

Abstract

The configuration of legal politics always influences the development (character) of legal products. democratic political configurations always give birth to responsive character laws, the Eradication and Prevention Policy on Corruption, Collusion and Nepotism, which states that there is a need for a law regulating witness protection. In the light of the Witness and Victim Protection Act, it turns out that the law on the protection of witnesses and victims in terms of legal politics has not yet been able to meet the needs of the community. There should have been a government policy in the form of a law to protect the reporting witnesses or also called the Whistleblower, as well as expert witnesses, meaning that the existing laws are not in accordance with community needs (not responsive to community development)

Keywords: Politics of Law, Legal Protection, Reporting Witness, Expert Witness

\section{PENDAHULUAN}

\section{Latar Belakang Masalah}

Di kalangan ahli hukum minimal ada dua pendapat yang mengemukakan mengenai hubungan kausalitas antara politik dan hukum. kaum idealis yang berpijak pada sudut dassolen mengatakan bahwa hukum harus mampu mengendalikan dan merekayasa perkembangan masyarakat dalam kehidupan politiknya.

Penulis seperti Rouscoe Pound telah lama berbicara tentang "Law as a too of social engineering" sebagai keinginan tentu wajar jika ada upaya untuk meletakkan hukum sebagai penentu arah perjlanan masyarakat karena dengan fungsi hukum untuk menjamin ketertiban dan melindungi kepentingan masyarakat akan menjadi relevan (Moch. Mahfud, MD, 1983:4).Van Savigny mengatakan bahwa hukum selalu berkembang sesuai dengan berkembangnya masyarakat, ini berarti bahwa hukum mau tidak mau menjadi dependent variable atas keadaan politiknya (JCT, Simorangkir, BS. Batoeah, 1997:106). Namun dalam kenyatannya hukum itu lahir sebagai refleksi dari konfigurasi politik yang melatar belakangi dengan kata lain kalimat-kalimat yang ada di

\footnotetext{
48 Tulisan ini Belum Merupakan Jurnal, Rangkuman Pemikiran dari Beberapa Ahli tentang Tema atau Judul.
} 
dalam aturan hukum itu, tidak lain merupakan kristalisasi dari kehendak politik yang saling bersaingan (Moch. Mahfud, MD, 1993:4)

Satjipto Rahardjo mengemukakan bahwa kalau kita melihat sub sistem politik dan sub sistem hukum, maka tampak bahwa politik memiliki konsentrasi energi yang lebih besar sehingga hukum selalu berada pada posisi yang lemah (Satjipto Rahardjo, 1982: 71)

Apabila kita berbicara tentang politik maka dalam implimentasinya pasti kita tidak terlepas juga berbicara masalah demokrasi, karena demokrasi dan hukum merupakan saudara kembar atau ibarat dua sisi dari sekeping uang, demokrasi tidak akan tegak dan diselewengkan tanpa terkendali jika tidak dikawal oleh hukum, sebaliknya hukum tidak dapat ditegakkan dengan benar jika sistem politiknya demokrasi, jadi keduanya ada hubungan interdependensi.

Sri Sumantri sering mengeluh bahwa perjlanan politik dan hukum di Indonesia ini ibarat perjalanan kereta api di luar rel (Sri Sumantri, 1990 : 79) artinya banyak sekali praktek hukum yang secara substantif bertentangan dengan aturan-aturan hukum. hal ini bermaksud memberi penegasan bahwa di dalam kenyataan empiriknya politik telah sangat menentukan bekerjanya hukum. Pengaruh politik terhadap hukum dapat berlaku terhadap penegakkan hukumnya maupun karakteristik produk-produk dan proses pembuatannya.

Philipe Nonet dan Philip Selznick (1978) pernah mengatakan bahwa tingkat perkembangan masyarakat tertentu dapat mempengaruhi pola penegakan hukumnya. Dikatakannya bahwa masyarakat yang baru dilahirkan harus menunjukkan dan membuktikan dirinya bisa menguasai keadaan, menguasai anggotanya, dan menciptakan ketertiban dengan komitmen politiknya yang utama adalah "ketertiban" selanjutnya dikatakan Nonet dan Selznick negara baru lebih mengutamakan tujuan dan isi dibandingkan prosedur dan aturan-aturan resmi untuk meraih substansi itu sehingga masalah prosedur atau cara tidak dipentingkan, yang penting adalah tujuan politisnya.

Keadaan politik-politik tertentu dapat mempengaruhi produk hukum, khusus untuk negara Indonesia produk-produk hukum dapat terpengaruh oleh keadaan politik / konfigurasi politik seperti dikemukan di atas oleh para sarjana bahwa konfigurasi politik dapat mempengaruhi terhadap produk-produk hukum. Begitu juga dengan Undang-Undang (UU) Perlindungan Saksi yang pada awalnya adalah amanat yang didasarkan Ketetapan MPR No. VIII Tahun 2001 tentang Rekomendasi Arah Kebijakan 
Pemberantasan dan Pencegahan Korupsi, Kolusi dan Nepotisme, yang menyatakan bahwa perlu adanya sebuah undang-undang yang mengatur tentang perlindungan saksi. Berdasarkan amanat TAP MPR tersebut, maka Badan Legislasi DPR RI kemudian mengajukan sebuah UU Perlindungan Saksi dan Korban pada tanggal 27 Juni 2002 dan ditandatangani oleh 40 anggota DPR dari berbagai fraksi sebagai RUU usul inisiatif DPR. Pada Rapat Paripurna ke-13 DPR RI Periode 2004-2009, yakni tanggal 1 February 2005 telah disetujui sebuah Program Legislasi Nasional. Ada sebanyak 284 rancangan undangundang (UU) disetujui untuk dijadikan prioritas pembahasan untuk periode 2005-2009. Dari 284 rancangan undang-undang (RUU) tersebut, 55 diantaranya ditetapkan sebagai rancangan undang-undang prioritas yang akan dibahas oleh DPR dan Pemerintah. Dari 55 RUU yang diprioritaskan untuk segera dibahas tersebut, salah satunya adalah RUU Perlindungan Saksi.

Selanjutnya pada tanggal 30 Agustus 2005 akhirnya Presiden SBY mengeluarkan sebuah Surat Presiden (Supres) mengenai kesiapan pemerintah untuk pembahasan RUU perlindungan Saksi dan sekaligus menunjuk menteri Hukum dan perundang-undangan sebagai wakil pemerintah dalam pembahasan tersebut. Turunnya Surpres tersebut sudah menunjukkan itikad baik dari pemerintah agar UU Perlindungan saksi dan Korban (selanjutnya di sebut RUU PSK) dapat segera di bahas di DPR. Hal tersebut kemudian di respon oleh Komisi III DPR RI yang menetapkan pembahasan RUU ini dalam bentuk Panja. Panitia Kerja (Panja) pembahasan RUU ini di bantu oleh wakil dari pemerintah telah melakukan pembahasan secara marathon sejak tanggal 8 februari 2006 sampai dengan tanggal 8 Juni 2006 dan akan terus menyelesaikan pembahasannya, hasil pembahasan tersebut akan di rumuskan oleh Tim Perumus (Timus) dan Penelitian Bahasa (Libas) yang akan diteruskan ke Rapat Komisi III dan selanjutnya akan di bawa ke rapat Pleno DPR.

Adapun pengertian Whistleblower menurut PP No.71 Tahun 2000 adalah orang yang memberi suatu informasi kepada penegak hukum atau komisi mengenai terjadinya suatu tindak pidana korupsi dan bukan pelapor. Adapun istilah pengungkap fakta (Whistleblower) dalam UU Nomor 13 Tahun 2006 tentang Pelindungan Saksi dan Korban tidak memberikan pengertian tentang "pengungkap fakta", dan berkaitan dengan itu hanya memberikan pengertian tentang saksi. Adapun yang disebut dengan saksi menurut UU No. 13 Tahun 2006 adalah orang yang dapat memberikan keterangan guna kepentingan penyelidikan, penyidikan, penuntutan, dan pemeriksaan di sidang 
pengadilan tentang suatu perkara pidana yang ia dengar sendiri, ia lihat sendiri, dan / atau ia alami sendiri. ${ }^{49}$

Sedangkan masalah korupsi sebagai salah satu alasan lahirnya UU ini merupakan permasalahan yang kompleks dan turun-temurun berjalan seiring, bahkan lebih cepat pertumbuhannya ketimbang urusan pemberantasan. Upaya pemberantasan korupsi yang terjebak dalam perdebatan selalu berjalan tertatih-tatih di belakang laju pertumbuhan taktik dan strategi paa pelaku korupsi. Di tengah-tengah perdebatan pemberantasan korupsi itu, akhir-akhir ini sering terdengar istilah Whistleblower sebagai salah satu pendekatan proses pemberantasan tindak pidana Tahun 2006 tidak mengakomodir kepentingan pemberantasan korupsi dengan tidak diaturnya mengenai permasalahan Whistleblower.

\section{Perumusan Masalah.}

Berdasarkan latar belakang masalah yang telah dikemukakan di atas, maka yang menjadi permasalahan adalah "Apakah seluruh kepentingan Saksi termasuk saksi Whistleblower telah terlindungi setelah keluarnya Undang-undang Perlindungan Saksi dan Korban?

\section{PEMBAHASAN}

Berdasarkan uraian latar belakang dan perumusan masalah yang ada di atas maka kami dapat menguraikan dalam pembahasan sebagai berikut:

\section{Definisi Saksi, Kurang Memadai dan Masih Dibebani oleh Konsep KUHAP sehingga Menutup Kemungkinan Perlindungan terhadap Whistleblower.}

Berdasarkan pengertian ini maka Undang-undang Perlindungan Saksi secara tegas menyatakan bahwa UU ini hanya berlaku bagi saksi dalam lingkup perkara pidana. Rumusan ini masih tetap menggunakan konsep tentang pengertian saksi seperti yang sudah diatur oleh Kitab Undang-undang Hukum Acara Pidana (KUHAP). Perbedaannya dengan rumusan KUHAP adalah bahwa status saksi dalam UU ini sudah dimulai di tahap penyelidikan sedangkan dalam KUHAP status saksi dimulai dari tahap penyidikan.

\footnotetext{
1. Pengertian saksi yang terdapat dalam Undang-Undang Nomor 13 Tahun 2006 adalah sama dengan pengertian saksi yang terdapat di dalam Undang-Undang Nomor 8 Tahun 1981 tentang Hukum Acara Pidana atau Kitab Undang-Undang Hukum Acara Pidana (KUHAP)
} 
Pengertian saksi dalam Undang-undang Perlindungan Saksi ini hanya sedikit lebih maju, karena berupaya mencoba memasukkan atau (memperluas) perlindungan terhadap orang-orang yang membantu dalam upaya penyelidikan pidana yang masih berstatus pelapor atau pengadu. Walaupun pun tidak secara tegas dinyatakan bahwa pelapor juga dilindungi, tapi para perumus berkeyakinan bahwa pelapor sudah tercakup dalam wilayah penyelidikan. Namun perlindungan terhadap status saksi dalam konteks penyelidikan ini pun masih terbatas dan kurang memadai karena terbentur pada doktrin yang di introdusir KUHAP, dimana saksinya haruslah orang yang keterangan perkara pidana yang ia dengar sendiri, ia lihat sendiri dan/atau ia alami sendiri. Doktrin ini sebenarnya berelasi kuat dengan "kekuatan nilai pembuktian" Penggunaan Doktrin dalam rumusan inilah yang kemudian akan membatasi perlindungan terhadap saksi yang mendengar, melihat dan /atau mengalami sebuah tindak pidana. Karena dalam banyak kasus ada orang yang berstatus pelapor ini kadangkala bukanlah orang yang mendengar, melihat atau mengalami sendiri perkara pidana tersebut. tapi orang yang informasinya merupakan hal yang penting dalam mengungkap sebuah kasus, sebagai contoh, mengetahui dimana informasi mengenai alat bukti di temukan, atau tempat dimana sebuah dokumen-dokumen pembuktian berada.

Oleh karena itu pula maka Undang-undang Perlindungan Saksi dan Korban ini sulit diterapkan untuk bisa melindungi orang orang yang berstatus saksi Whistleblower (kalaupun bisa, mereka haruslah melihat, mendengar dan/atau mengalami tindak pidana). Secara umum pengertian Whistleblower adalah orang-orang yang mengungkapkan fakta kepada publik mengenai sebuah skandal, bahaya, malpraktik, maladministrasi maupun korupsi.

Dalam berbagai negara kasus yang menjadi perhatian dalam konteks Whistleblower terkait dengan perbuatan yang melanggar hukum, perbuatan yang tidak pantas, dan kelalaian yang mempengaruhi kepentingan umum; bahaya terhadap kesehatan dan keselamatan umum; dan bahaya terhadap lingkungan . Oleh karena itu maka konteks Whistleblower ini tidak hanya mencakup masalah criminal (pidana) tapi mencakup bidang yang lebih luas.

Dalam prakteknya dibedakan antara Whistleblower dengan para pelapor dan informan. Namun perbedaan utamanya adalah para Whistleblower tidak akan memberikan kesaksiannya langsung di muka persidangan (peradilan), jadi jika ia memberikan kesaksiannya ke muka persidangan, maka statusnya kemudian menjadi 
"saksi". Para Whistleblower ini sangat rentan akan intimidasi dan ancaman karena status hukumnya (di Indonesia) tidak diakui. Dalam kasus pidana korupsi, mereka biasanya disebut sebagai para pelapor (dikategorikan saja secara sederhana berdasarkan KUHAP).

Oleh karena itu UU Perlindungan Saksi sebaiknya juga melindungi orang-orang yang berstatus Whistleblower ini walaupun terbatas pada konteks kasus pidana. Jika kita bandingkan rumusan UU itu dengan UU tentang perlindungan saksi di negara yang sudah lebih dahulu menerapkan perlindungan saksi, cara merumuskan "orang terkait ini" berbeda. UU Perlindungan Saksi di Afrika Selatan misalnya, UU tersebut menyatakan bahwa saksi berarti setiap orang yang sedang atau dapat diminta, atau yang telah memberi kesaksian dalam suatu persidangan. Dalam UU perlindungan Saksi Kanada. malah tidak mendefenisikan saksi, namun langsung menyatakan bahwa seorang yang dapat ikut dalam program perlindungan saksi ini adalah a) seseorang yang memberikan atau setuju untuk memberikan informasi atau bukti atau yang ambil bagian dalam suatu hal yang terkait dengan suatu penyelidikan atau investigasi atau penuntutan suatu kejahatan, dan yang mungkin membutuhkan perlindungan karena resiko keamanan atas dirinya dalam kaitan dengan penyelidikan, investigasi, atau penuntutan tersebut. UU Perlindungan Saksi di Quensland Australia juga menyatakan bahwa seseorang yang boleh diikutsertakan ke dalam perlindungan saksi adalah orang yang membutuhkan perlindungan dari suatu bahaya yang muncul karena orang tersebut telah membantu, atau sedang membantu, suatu badan penegak hukum dalam menjalankan fungsinya;

\section{Melupakan Perlindungan bagi Ahli (Saksi Ahli)}

Di dalam Undang-undang perlindungan saksi dan korban tidak ada memuat perlindungan bagi saksi ahli, sedangkan dalam prakteknya saksi ahli bahakan sangat menentukan dalam pembuktian perkara pidana ketika suatu peristiwa pidana terjadi , hal tersebut juga akan menutup perlindungan bagi orang orang yang berkeahlian khusus yang telah memberikan bantuan kepada aparat penegak hukum untuk keterangan dan membantu proses pemeriksaan pidana yang dalam KUHAP disebut berstatus ahli.

Pembatasan terhadap Saksi yang akan Dilindungi, Merupakan Kemunduran Tambahan ketentuan pembatasan atau kategori saksi yang berhak mendapatkan perlindungan dalam program perlindungan saksi di LPSK dalam pasal baru ini merupakan sebuah kemunduran dari UU Perlindungan Saksi. Argumentasi PANJA riwayat atas munculnya pasal ini sebagian besar dilatar belakangi untuk mengurangi beban pembiayaan pemerintah agar biaya yang akan diberikan untuk perlindungan tidak 
terlalu besar. Argumentasi kedua adalah: mekanisme ini merupakan "alat penyaring" atas kasus-kasus yang akan masuk ke LPSK sehingga beban LPSK akan diminimalisir.

\section{Konsep “saksi terkait” Haruslah Diperluas}

PANJA dalam riwayat perumusan UU perlindungan saksi dan korban di legislatif lebih memilih pihak-pihak yang bisa dilindungi ini hanya terbatas kepada keluarga saksi. Poin 4 Pasal UU PSK menjelaskan tentang siapa yang dimaksud dengan keluarga saksi, yakni orang-orang yang mempunyai hubungan darah dalam garis lurus, atau mempunyai hubungan darah dalam garis menyamping sampai derajat ketiga, atau mempunyai hubungan perkawinan dengan saksi dan atau orang-orang menjadi tanggungan saksi dan atau korban. Rumusan ini terlalu sempit, seharusnya konsep orang terkait ini tidak hanya menjangkau keluarga, namun dapat menjangkau orang lain yang mempunyai potensi membuat saksi tidak mau bersaksi bila orang tersebut di intimidasi.

Jika kita bandingkan rumusan UU perlindungan itu dengan UU tentang Perlindungan Saksi di negara yang sudah lebih dahulu menerapkan perlindungan saksi, cara merumuskan "orang terkait ini" berbeda. UU Perlindungan Saksi di Afrika Selatan misalnya, UU tersebut menyatakan orang terkait berarti setiap anggota keluarga saksi atau orang-orang lain yang memiliki hubungan dekat

atau kekerabatan dengan saksi tersebut. Di dalam UU perlindungan Saksi Kanada mendefenisikan saksi terkait adalah seseorang yang karena hubungan atau ikatannya dengan orang yang disebut pada bagian diatas mungkin juga membutuhkan perlindungan karena alasan yang sama seperti diatas. UU Perlindungan Saksi di Quensland Australia juga menyatakan bahwa seseorang yang boleh diikutsertakan ke dalam perlindungan saksi adalah orang yang membutuhkan perlindungan dari suatu bahaya yang muncul - karena orang tersebut telah membantu, atau sedang membantu, suatu badan penegak hukum dalam menjalankan fungsinya; atau karena hubungan atau ikatan orang tersebut dengan seseorang yang telah membantu, atau sedang membantu, suatu badan penegak hukum dan menjalankan fungsinya.

Kalau kita merujuk kepada pendapat seperti Rouscoe Pound telah lama berbicara tentang "Law as a too of social engineering" sebagai keinginan tentu wajar jika ada upaya untuk meletakkan hukum sebagai penentu arah perjlanan masyarakat karena dengan fungsi hukum untuk menjamin ketertiban dan melindungi kepentingan masyarakat akan menjadi relevan, namun apabila kita melihat undang-undang ini malah menghambat untuk tercapainya. 
Pengertian tentang saksi terkait yang lebih luas seperti contoh-contoh di UU negara lain ini sebetulnya yang perlu dijadikan rumusan, karena saksi dalam pengertian untuk dapat terlibat dalam program perlindungan bukan saja saksi itu sendiri dan keluarga saksi tetapi juga pihak pihak lain yang ada ikatan atau hubungan dengan saksi yang juga mungkin juga membutuhkan perlindungan. Ketentuan mengenai dapat dimasukkannya pihak lain selain saksi dan keluarga saksi sebagai bagian pengertian saksi yang dapat menerima perlindungan karena ada ikatan dengan saksi akan menjamin bahwa pihak-pihak lain yang mempunyai hubungan dengan saksi mendapatkan perlindungan. Dalam kenyataannya, pihak-pihak yang perlu dilindungi adalah termasuk pihak-pihak yang mempunyai kedekatan atau hubungan dengan saksi bukan hanya dari keluarga saksi. Pengaturan tentang dicantumkannya pihak lain diluar keluarga saksi tapi ikut berpengaruh terhadap seorang saksi akan lebih menjamin bagi seorang saksi untuk memberikan kesaksian.

\section{Tidak Ada Kejelasan, Saksi dari Pihak Manakah yang Harus Dilindungi?}

Undang-undang perlindungan juga tidak jelas mengatur "status saksi" berkaitan dengan saksi dari pihak manakah yang bisa dilindungi. Apakah saksi yang membantu pihak tersangka/ terdakwa (a charge) ataukah saksi dari pihak yang membantu pihak aparat penegak hukum (a de charge). Tidak di cantumkannya secara tegas hal ini nantinya akan menimbulkan problem dan membebani lembaga perlindungan dalam pelaksanaannya. Seharusnya, UU ini menegaskan bahwa saksi yang dilindungi dalam UU ini adalah saksi yang statusnya membantu aparat penegak hukum.

Menurut sejarahnya Whistleblower sangat erat dengan organisasi kejahatan ala mafia sebagai organisasi kejahatan tertua dan terbesar di Italia yang berasal dari Palermo, Sicilia, sehingga sering disebut Sicilian Mafia atau Cosa Nostra. Kejahatan terorganisasi yang dilakukan oleh Mafioso (sebutan terhadap anggota mafia) bergerak di perdagangan heroin dan berkembang di berbagai belahan dunia, sehingga kita mengenal organisasi sejenis diberbagai negara seperti Mafia di Rusia, Cartel di Kolombia, Triad di China, dan Yakuza di Jepang.

Begitu kuatnya jaringan organisasi kejahatan tersebut sehingga orang-orang mereka bisa menguasai berbagai sektor kekuasaan, apakah itu eksekutif, legislatif maupun yudikatif termasuk aparat penegak hukum. Tidak jarang suatu sindikat bisa terbongkar karena salah seorang dari mereka ada yang berkhianat. Artinya, salah seorang dari mereka melakukan tindakan sendiri sebagai "peniup pluit" (Whistleblower) 
untuk menggungkap kejahatan yang mereka lakukan kepada publik atau aparat penegak hukum. Sebagai imbalannya maka Whistleblower tersebut akan dibebaskan dari segala tuntutan hukum.

Dalam Bahasa Belanda istilah politik hukum disebut Rechts politek dalam Bahasa Inggeris dinamakan Legal Lolicy Politik hukum merupakan kebijaksanaan strategis yang menentukan hukum yang seharusnya berlaku dalam negara atau masyarakat. Menurut E. Utrecht / Moh. Saleh Djindang, SH menyatakan : hukum menjadi juga objek politik yaitu objek dari politik hukum. politik hukum berusaha membuat kaedah-kaedah yang akan menentukan bagaimana seharusnya manusia bertindak. Menyelidiki perubahanperubahan apa yang akan diadakan dalam hukum yang sekarang berlaku supaya menjadi sesuai dengan kenyataan sosial. Politik hukum meneruskan perkembangan hukum dengan berusaha melenyapkan sebanyak-banyaknya keterangan positivitas dan realitas sosial. Kemudian R. Otje Salman, SH menyatakan politik hukum yaitu kegiatan memilih dan menerapkan nilai-nilai.

Dan seterusnya Dr. Soedjono Dirdjo Sisworo, SH menyatakan : Politik hakikatnya adalah sarana untuk mencapai tujuan tersebut yang untuk itu dinilai proses pemilihan tujuan. Oleh karenanya politik adalah juga aktifitas memilih tujuan tertentu. Dalam hukum dijumpai keadaan yang sama. Hukum yang berusaha memilih tujuan dan cara mencapai tujuan tersebut adalah termasuk bidang politik hukum. jelaslah bahwa politik hukum adalah disiplin hukum yang mengkhususkan dirinya pada usaha memerankan hukum dalam mencapai tujuan yang dicita-citakan oleh masyarakat.

Kebijaksanaan politik hukum merupakan salah satu sub sistem dan bagian yang integral dalam sistem hukum itu sendiri. Pembentukan sistem hukum yang diinginkan yaitu sistem hukum nasional, perlu diperhatikan konsistensinya dengan konsepsi teoritis maupun pertimbangan operasional terutama dengan dasar-dasar manajemen, kehidupan bangsa Indonesia sebagaimana diamanatkan oleh Pancasila UUD 1945 serta Garis-garis Besar Haluan Negara. Bertitik tolak dari tujuan negara menurut konstitusi dengan memperhatikan potensi, kemampuan sumberdaya yang dimiliki seraya memperhatikan kondisi yang mempengaruhi baik dalam lingkup nasional maupun regional dan global yang akhirnya menetapkan politik pembangunan hukum nasional termasuk pembinaannya dan juga pembaharuannya.

Konfigurasi politik diartikan sebagai susunan atau konstelasi kekuatan politik yang secara dikatomis dibagi atas dua konsep yang bertentangan secara diametral, yaitu 
konfigurasi politik demokratis dan konfigurasi politik otoriter. Pengertian konseptual dan indikator-indikator ini adalah :

a. Konfigurasi politik demokratis adalah susunan sistem politik yang membuka kesempatan bagi partisipasi rakyat secara penuh untuk ikut aktif menentukan kebijaksanaan umum. Partisipasi ini ditentukan atas dasar mayoritas oleh wakil-wakil rakyat dalam pemilihan-pemilihan berkala yang didasarkan atas prinsip kesamaan politik dan diselenggarakan dalam suasana terjadinya kebebasan politik.

Di negara yang menganut sistem demokrasi atau konfigurasinya demokratis terdapat pluraritas organisasi di mana organisasi-organisasi penting relatif otonom. (Mahfud MD 1985 8-9)

Dilihat dari hukum antara Pemerintah dan wakil rakyat, di dalam konfigurasi politik demokratis ini terdapat kebebasan bagi rakyat melalui wakil-wakilnya untuk melancarkan kritik terhadap pemerintah

b. Konfigurasi politik otoriter adalah susunan sistem politik yang lebih memungkin negara berperan sangat aktif serta mengambil hampir seluruh inisiatif dalam pembuatan kebijaksaan negara. Konfigurasi ini ditandai dorongan elit kekuasaan untuk memaksakan persatuan, penghapusan oposisi terbuka, dominasi pimpinan negara untuk menentukan kebijaksanaan negara dan dominasi kekuasaan politik oleh elit politik yang kekal, serta dibalik semua itu ada satu doktrin yang membenarkan konsentrasi kekuasaan.

Untuk mengkualifikasikan apakah konfigurasi politik itu demokratis atau otoriter, indikator yang dipakai adalah bekerjanya tiga pilar demokrasi yaitu peranan partai politik, dan badan perwakilan, kebebasan pers dan peranan eksekutif. Pada konfigurasi politik demokratis partai politik dan lembaga perwakilan rakyat aktif menentukan hukum negara atau politik nasional. Kehidupan pers lebih bebas sedangkan peranan lembaga eksekutif tidak dominan dan tunduk pada kemauan rakyat yang digambarkan lewat kehendak lembaga perwakilan rakyat. Sedangkan pada konfigurasi politik otoriter adalah sebaliknya.

Kalau kita kaitkan dengan konfigurasi politik hukum penerapan undang-undang perlindungan saksi dan korban dalam rangka mewadahi Whistleblower dalam pengungkapan pidana korupsi, Whistleblower biasanya ditujukan kepada seseorang yang 
pertama kali mengungkap atau melaporkan suatu tindak pidana atau tindakan yang dianggap ilegal di tempatnya bekerja atau orang lain berada, kepada otoritas internal organisasi atau kepada publik seperti media massa atau lembaga pemantau publik. Pengungkapan tersebut tidak selalu didasari itikad baik sang pelapor, tetapi tujuannya untuk mengungkap kejahatan atau penyelewengan yang diketahuinya.

Dilihat dari sorotan tentang Undang-undang Perlindungan Saksi dan Korban tersebut, ternyata undang-undang perlindungan saksi dan korban dari segi politik hukum pemberlakuan undang-undang tersebut belumlah dapat memenuhi kebutuhan masyarakat, untuk mengetahui apakah sebab terjadi demikian perlu penelitian lebih lanjut sebab mungkin saja pembentukan undang-undang ini sangat tergesa-gesa sehingga tanpa dilakukan penelitian sosiologi secara mendalam dalam masyarakat atau ada kepentingan tertentu dari pembuat undang-undang yang merupakan sebagai elit masyarakat, oleh karena itu undang-undang perlindungan Saksi dan korban belumlah dapat dikatakan sebagai hukum yang hidup dalam masyarakat (Volkgeist) sebagaimana yang dikemukakan oleh Von Savigny yang seharusnya hukum itu merupakan bagian sistem sosial yang lebih luas dan antara sistem hukum dengan aspek-aspek sistem sosial lainnya terdapat hubungan timbal saling pengaruh mempengaruhi.

Demikian juga menurut Eugen Ehrlich yang merupakan pelopor aliran sosiologika Jurusprudency menyatakan hukum positif hanya akan efektif apabila selaras dengan hukum yang hidup dalam masyarakat dan pusat perkembangan hukum bukanlah terletak pada badan-badan legislatif, keputusan badan yudikatif ataupun ilmu hukum, akan tetapi justru terletak di dalam masyarakat itu sendiri.

Jadi Undang-undang Perlindungan Saksi dan Korban belumlah dapat diterima oleh masyarakat karena itu Undang-undang Perlindungan Saksi dan Korban belum dapat dikatakan sebagai Undang-undang yang responsive.

\section{PENUTUP}

\section{Kesimpulan.}

1. Konfigurasi politik selalu mempengaruhi perkembangan (karakter) produk hukum. konfigurasi politik yang demokratis selalu melahirkan huh-hukum yang berkarakter responsif, sedangkan konfigurasi politik otoriter selalu menghasilkan hukum-hukum yang berkarakter konservatif / ortodok. 
2. Politik hukum merupakan kebijaksanan strategis yang menentukan hukum yang seharusnya berlaku dalam suatu negara atau masyarakat. politik hukum memegang peranan penting dalam upaya tercipta suatu undang-undang yang responsif karena melalui hukum dapat dikaji secara mendalam hukum atau undang-undang seperti apa yang dibutuhkan dalam masyarakat.

3. Kebijaksanaan politik hukum merupakan salah satu sub sistem dan bagian yang integral dalam sistem hukum itu sendiri. Pembentukan sistem hukum yang diinginkan yaitu sistem hukum nasional, perlu diperhatikan konsistensinya dengan konsepsi teoritis maupun pertimbangan operasional terutama dengan dasar-dasar manajemen, kehidupan bangsa Indonesia sebagaimana diamanatkan oleh Pancasila UUD 1945 serta Garis-garis Besar Haluan Negara.

4. Dilihat dari sorotan tentang Undang-undang Perlindungan Saksi dan Korban tersebut, ternyata undang-undang perlindungan saksi dan korban dari segi politik hukum pemberlakuan undang-undang tersebut belumlah dapat memenuhi kebutuhan masyarakat.

\section{Saran-saran}

1. Seharusnya sudah ada kebijakan pemerintah dalam bentuk undang-undang untuk melindungi saksi pelapor atau di sebut juga dengan Whistleblower, begitu juga dengan saksi ahli, artinya undang-undang yang ada sekarang tidak sesuai dengan kebutuhan masyarakat (tidak responsive terhadap perkembangan masyarakat)

2. Seharusnya sudah ada politik hukum yang bersifat responsif terhadap perlindungan saksi dan korban di Negara ini, kalau bisa dikatakan pemerintah atau presiden sebagai pemegang pedang pemberantasan korupsi sekarang, tapi kenyataanya tidak kelihatan poliik hukum apa yang ada dalam pembentukan undang-undang perlindungan saksi dan korban yang tidak sesuai dengan kebutuhan masyarakat sekarang ini (tidak responsive)

\section{BIBLIOGRAPHY}

Arbi Sanit, 1993, Sistem Politik Indonesia, PT. Grafindo Persada, Jakarta, Alfian, 1992, Pemikiran dan Perubahan politik Indonesia, PT, Gramedia,. 
Boestam Ambia, 2000, Pokok-pokok pikiran pemberdayaan dan profesionalisme legislatif dalam pembuatan Produk Hukum yang responsif, Makalah disampaikan dalam Lokakarya dan temu ilmiah Nasional Hukum Indonesia di Fakultas Hukum UGM, Yogyakarta, 21 Maret.

Lubis M. Solly, 1988, Sistem Hukum Nasional Sebuah Pengantar Studi dengan Pendekatan Sistem dan Pandangan Konseptual strategis, USU, Pres, Medan Moch. Mahfud. MD, 1993, Demokratisasi Konstitusi Indonesia, Liberty, Yogyakarta,. -, 1993, Perkembangan Politik Hukum di Indonesia, Disertasi Doktor dalam Ilmu Hukum UGM, Yogyakarta,. -, 1996, Pengaruh Demokrasi dan Keadaan Politik Terhadap Proses

Penegakan Hukum, Orasi Ilmiah Pembukaan Pelatihan Praktisi Hukum Angkatan Ke IV, UII, Yogyakarta,.

---------------, Konfigurasi politik dan Hukum, Majalah Prisma No. 7 Bulan Juli 1995. 1995, Serba Serbi tentang Politik dan Hukum, Bahan Kuliah Materi Kuliah Program magister (S2) Ilmu Hukum UII..

Sumber: http://id.shvoong.com/law-and-politics/law/2027081-pengertian-korupsidan-tindak-pidana/\#ixzz27rytfx4M diakses tanggal 24 september 2012 


\title{
KEWENANGAN PEGADAIAN DALAM MENERBITKAN SERTIFIKAT BATU MULIA DI INDONESIA
}

\author{
Alif Arhanda Putra \\ Fakultas Hukum, Universitas Borneo Tarakan \\ Tarakan, Kalimantan Utara, Indonesia \\ alifarhanda@gmail.com
}

\begin{abstract}
Authority of Pegadaian in Issuance of the Certificates of Precious Stones in Indonesia.

This research aimed to determine the institution authorized to issue the certificate of the precious stones in Indonesia. This study used the empirical research type to look at the enforcement of the law from the non-legal aspect. The collected data - both primary and secondary data - were analyzed qualitatively. Then, they were described in order to answer the problems of this research.

The research results revealed that The authority to issue certificates for the precious stones in Indonesia was given to the authorized and powerful institutes in order to issue certificates for the precious stones in Indonesia, such as the Pawnshop and order private institutes as the actors in the commerce industry of precious stones in Indonesia.
\end{abstract}

Keywords: Authority, The Pawnshop, Certificates of Precious Stones.

\section{Pendahuluan}

Batu mulia adalah segala jenis batuan, mineral, dan bahan alam lainnya termasuk beberapa jenis bahan organik, yang setelah diproses dengan sentuhan teknologi, memiliki keindahan dan ketahanan yang mencukupi untuk dijadikan sebagai batu permata. Seperti halnya istilah diamond yang mencakup intan sebagai bahan mentah dan berlian setelah intan itu diproses menjadi batu permata, maka pengertian batu mulia yang bahasa Inggrisnya gemstone mencakup segala bahan mentah yang dapat diproses menjadi batu permata.

Perkembangan batu mulia Indonesia sejak setahun terakhir ini menunjukkan perkembangan yang sangat menggembirakan menyusul publikasi dan promosi yang dilancarkan secara luas dan terus menerus oleh Majalah Gemstone yang terbit sebulan sekali sejak Oktober 2013. Beragam jenis batu mulia, baik temuan lama ataupun temuan baru, ditampilkan di majalah berwarna tersebut berikut tokoh-tokoh terkemuka batu mulia Indonesia, seperti misalnya krisopras Ohen dan pancawarna Edong dari Garut (Jawa Barat), opal dari Banten, jasper hijau dari Klawing Purbalingga (Jawa Tengah), akik Kladen dari Pacitan (Jawa Timur), kalsedon biru dari Baturaja (Sumatra Selatan), 